\title{
Klasifikasi Tingkat Kepuasan Mahasiswa Terhadap Pembelajaran Secara Daring Menggunakan Algoritma Naïve Bayes
}

\author{
Aminatuzzuhriyyah \\ Universitas Singaperbangsa Karawang \\ Karawang, Indonesia \\ ami.natuzzuhriyyah17051@student.unsika.ac.id
}

\author{
Nisa Nafisah \\ Universitas Singaperbangsa Karawang \\ Karawang, Indonesia \\ nisa.nafisah17162@student.unsika.ac.id
}

\begin{abstract}
Abstrak - Semenjak Penyebaran Covid19 di Indonesia semakin meningkat pada awal Maret 2020 menyebabkan aktivitas Lembaga Pendidikan terganggu, sehingga Menteri Pendidikan mengeluarkan surat edaran No. 3 tahun 2020 mengenai pencegahan covid19 yang menyatakan bahwa meliburkan sekolah dan perguruan tinggi. Sebagai gantinya kegiatan pembelajaran konvensional menjadi daring. Pembelajaran daring di Universitas Singaperbangsa dimulai sejak adanya peraturan dari kemdikbud RI, dari pembelajaran secara daring tersebut mempengaruhi konsentrasi, kendala seperti signal, suasana pembelajaran dan cara mengajar, sehingga faktor mempengaruhi tingkat kepuasan mahasiswa dalam pembelajaran. Penelitian ini bertujuan untuk mengetahui tingkat kepuasan mahasiswa terhadap pembelajaran daring menggunakan Metodologi CRISP-DM dan algoritma naive bayes dengan menggunakan tools rapidminer dengan hasil yang didapatkan yaitu tingkat akurasi sebesar $76,92 \%$, class precission $100.00 \%$, class recall $57.14 \%$ serta nilai AUC 0.881 atau mendekati angka 1 jadi model yang dihasilkan baik. Dengan kata lain, dari hasil yang didapatkan menggunakan algoritma naïve bayes dapat digunakan sebagai bahan untuk pengambilan keputusan tingkat kepuasan pembelajaran secara daring.
\end{abstract}

Kata kunci - Pembelajaran Daring, CRISP-DM, Algoritma Naive BayesPendahuluan

\section{PEndahuluan}

\section{A. Latar Belakang}

Semenjak adanya corona virus (severe acute respiratory syndrome coronavirus 2) yaitu penyakit karena infeksi virus yang biasanya disebut dengan covid19 merupakan virus yang menyerang ke sistem pernapasan manusia dan dapat menular ke siapa saja seperti anak-anak, golongan usia lanjut atau lansia, ibu hamil, ibu menyusui bahkan bayi dengan masing-masing gejala yang didapatkan berbeda seperti gejala ringan, sedang dan pemulihan atau karantina tanpa perlu ke rumah sakit. Pandemi ini memberikan dampak untuk seluruh kehidupan manusia pada aktivitas yang sering dilaksanakan pada masa sebelum wabah ini seperti pendidikan yang awalnya berinteraksi dengan guru dilakukan secara tatap muka sedangkan karena adanya pandemi ini pendidikan sangat terganggu sehingga pemerintah harus membuat dan mengambil keputusan untuk menutup sekolah untuk sementara dengan pembelajaran dilakukan secara daring.

Model pembelajaran merupakan suatu desain untuk menciptakan situasi lingkungan untuk menungkinkan siswa berinteraksi sehinnga ada perkembangan pada proses pembelajaran yang didapatkan [3]. Sebelum adanya pandemi covod19 ini pembelajaran secara konvensional dilakukan untuk proses pembelajaran berlanjut, Menteri Pendidikan mengeluarkan surat edaran No. 3 tahun 2020 mengenai pencegahan covid19 yang menyatakan bahwa meliburkan sekolah dan perguruan tinggi. Sebagai gantinya kegiatan pembelajaran yang sebelumnya dilakuakan secara konvensional dirumah melalui kebijakan menjadi pembelajaran jarak jauh dengan memanfaatkan teknologi atau daring [4].

Penutupan sementara Lembaga Pendidikan untuk mencegah penyebaran virus ini berdampak pada pelajar, dimana proses dalam pembelajaran berlangsung mempengaruhi psikologis anak didik dan menurunnya kualitas keterampilan murid dengan pelaksanaan pembelajaran berlangsung secara online atau daring yang skalanya belum pernah terukur dan teruji sebelumnya [1]. Sehingga, dampak yang dialami dari tingkat kepuasan maupun pemahaman pada materi yang telah disampaikan yaitu berdampak pada nilai, pengetahuan, Kerjasama dan keterampilan yang didapatkan oleh pelajar di lembaga pendidikan. Seperti, perguruan tinggi, SMA/SMK, SMP bahkan sampai dengan sekolah dasar.

Untuk memutus rantai penyebaran covid19 perguruan tinggi negeri di Karawang yaitu Universitas Singaperbangsa Karawang melaksanakan pembelajaran di rumah dengan jarak jauh atau daring dengan berinteraksi antara dosen pengampu dan mahasiswa dilakukan melalui classroom, whatsapp, zoom, google meet dan media lainnya yang mendukung pelajaran. Dalam proses belajar tersebut tingkat kepuasan dan pemahaman mahasiswa terhadap matakuliah sangat penting untuk menghasilkan mahasiswa yang berkualitas dari materi atau pembelajaran yang disampaikan.

Pada penelitian sebelumnya, menggunakan algoritma nä̈ve bayes untuk klasifikasi kepuasan mahasiswa terhadap pelayanan perguruan tinggi dengan hasil menunjukan dari 213 mahasiswa hasil dari pengujian klasifikasi menggunakan naïve bayes yang dilakukan accuracy 96,24\%, precission 93,14\%, dan recall 98,96\% [2]. Penelitian selanjutnya yaitu prediksi tingkat pemahaman mahasiwa terhadap mata kuliah berdasarkan posisi duduk dengan menggunakan algoritma naïve bayes hasil pengujian menunjukkan akurasi yang didapatkan sebesar $88.24 \%$ yaitu dengan 8 responden menyatakan ketidakpahaman sedangkan 60 responden lainnya menyatakan paham terhadap tingkat pemahaman mahasiswa terhadap matakuliah [7]. 
Berdasarkan uraian diatas, penelitian ini menggunakan metode klasifikasi yaitu algoritma naïve bayes untuk menghasilkan tingkat kepuasan dari mahasiwa terhadap mata kuliah serta tujuan yang diharapkan dari hasil ini dapat memberikan masukan serta perbaikan dalam pembelajaran yang diberikan kepada mahasiswa dalam menerima materi.

\section{B. Pertanyaan Penelitian}

Pertanyaan penelitian ini yaitu:

1. Bagaimana mengklasifikasikan tingkat kepuasan mahasiswa terhadap pembelajaran daring menggunakan algoritma naïve bayes?

2. Bagaimana hasil akurasi dari perhitungan menggunakan algoritma naïve bayes?

\section{Tujuan Penelitian}

Tujuan dari penelitian ini yaitu:

1. Untuk mengklasifikasikan tingkat kepuasan Mahasiswa terhadap pembelajaran daring menggunakan algoritma naïve bayes.

2. Untuk mengetahui hasil dari akurasi yang telah didapatkan dengan menggunakan algoritma naïve bayes.

\section{METODOLOGI PENELITIAN}

\section{A. Objek Penelitian}

Objek penelitian ini mengenai tingkat kepuasan mahasiswa dalam pembelajaran secara daring di program study Pendidikan Bahasa dan Sastra Indonesia (PBSI) Universitas Singaperbangsa Karawang.

\section{B. Pengumpulan Data}

1. Kuesioner/Angket Teknik pengumpulan data yang digunakan pada penelitian ini yaitu kuesioner/angket online dengan menggunakan google form untuk membuat pertanyaan kepada responden kemudian mengisi kuesioner yang telah dibagikan, kemudian menggunakan.

2. Metode Studi Pustaka yaitu dengan mengumpulkan referensi dari beberapa literatur yang dibutuhkan atau dapat mendukung penelitian untuk landasan teori dalam pembuatan laporan

\section{Analisis Data}

1. CRISP-DM merupakan standarisasi suatu data mining yang disusun oleh tiga data mining market yaitu Daimler Chrysler (Daimler-Benz), SPSS (ISL), CR. Kemudian dikembangkan pada berbagai workshops (antara 1997-1999). Lebih dari 300 organisasi yang berkontribusi dalam proses modelling ini dan akhirnya CRISP-DM 1.0 dipublikasikan pada 1999 (Shearer, 2000) dengan mempunyai 6 fase pada CRISP-DM yaitu:

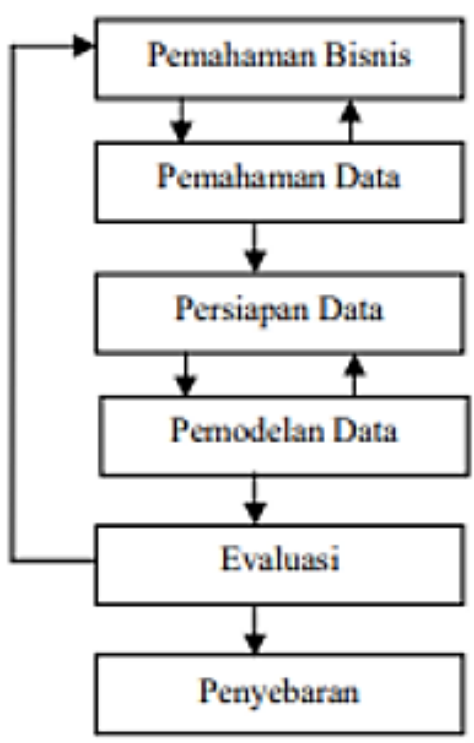

Enam tahapan metode CRISP-DM yaitu:

Gambar 1 Penerapan CRISP-DM

a. Pemahamam Bisnis (Bussiness Understanding) yaitu untuk menentukan sasaran maupun tujuan bisnis atau memahami situasi untuk menentukan tujuan data mining dan membuat perencanaan serta jadwal penelitian yang dilakukan

b. Pemahaman Data (Data nderstanding)yaitu pada tahap ini mempelajari data awal yang telah dikumpulkan untuk mengenal data yang akan digunakan atau mengidentifikasi masalah yang berkaitan dengan kualitas dari suatu data untuk memebuat hipotesis awal untuk data understanding

c. Persiapan data (Data Preparation) yaitu tahap ini dilakukan utnuk pemilihan table dan field untuk bahan data mining 
d. Pemodelan Data (Modeling) yaitu untuk menentukan tools data mining, teknik data mining yang digunakan serta menentukan parameter nilai yang optimal

e. Evaluasi (Evaluation) yaitu untuk interpretasi hasil data mining yang telah didapatkan untuk pemodelan dan fase sebelumnya untuk menyesuaikan model agar sesuai dengan tujuan yang ingin dicapai dari awal.

f. Penyebaran (Deployment) yaitu tahap akhir dengan penyusunan laporan atau presentasi dari evaluasi data mining yang telah didapatkan pada fase-fase yang telah digunakan sebelumnya.

2. Algoritma Nä̈ve Bayes

Algoritma naïve bayes yaitu metode probabilitas dan statistik metode ini diperkenalkan pertama kali oleh Thomas Bayes seorang ilmuan dari Inggris untuk memprediksi peluang yang terjadi dimasa depan dengan pengalaman sebelumnya atau dinamakan dengan teorema bayes

$$
P(H \mid X)=\frac{P(X|H| P(H)}{P(X)}
$$

Keterangan:

- $\quad \mathrm{X}=$ class dari data yang belum diketahui

- $\quad \mathrm{H}=$ Hipotesis dari $\mathrm{X}$ atau suatu class Spesifik

- $\quad \mathrm{P}(\mathrm{H} \mid \mathrm{X})=$ probabilitas hipotesis $\mathrm{H}$ berdasarkan dari kondisi $\mathrm{X}$ (posteriori probability)

- $\quad \mathrm{P}(\mathrm{H})=$ Probabilitas dari Hipotesis $\mathrm{H}$ (prior probability).

- $\quad \mathrm{P}(\mathrm{X} \mid \mathrm{H})=$ Probabilitas $\mathrm{X}$ berdasar kondisi pada Hipotesis $\mathrm{H} \mathrm{P}(\mathrm{X})=$ Probabilitas dari X..

\section{HASIL DAN PEMBAHASAN}

\section{A. Business Understanding}

Pada awal tahun 2020 aktivitas Lembaga Pendidikan diberhentikan sementara untuk mencegah penyebaran virus yang semakin meningkat setiap harinya sehingga pembelajaran dilakukan secara daring dari pemahaman tersebut maka tujuan dari penelitian untuk mengetahui dan mengelompokan tingkat kepuasan pembelajaran secara daring dimasa pandemi ini.

\section{B. Data Understanding}

Pada tahapan ini yang dilakukan yaitu:

1. Mendeskripsikan data yaitu data set mahasiwa baru yang didapatkan dengan menyebarkan kuesioner dengan menggunakan google form total responden yang mengisi kuesioner sebanyak 51 mahasiswa dari beberapa pertanyaan yang dibuat dan terdiri dari data nominal.

2. Pemilihan atribut yang digunakan yaitu jenis kelamin, penggunaan media belajar daring, mudah berkonsentrasi, kendala (signal), suasana pembelajaran, cara mengajar, komunikasi dan penyampaian materi.

\section{Data Preparation}

Data pada tahap modelling agar akurat maka pada tahap ini, data sebayak 51 dengan jumlah atribut sebanyak 8 akan dilakukan pemeriksaan data. Hasil yang didapatkan terdapat data yang tidak konsisten pada atribut cara mengajar yaitu Menyenagkan menjadi Menyenangkan.

\section{Modeling}

Dari data yang telah didapatkan pada tahap preparation, maka pemodelan yang digunakan yaitu metode klasifikasi dengan menggunakan algoritma naïve bayes. Pada tahapan ini terdapat perhitungan manual naïve bayes dan menggunakan tools rapidminer sebagai pemodelannya.

1. Perhitungan Manual

Perhitungan manual yang dilakukan yaitu mencari probabilitas puas dan tidak puas dari atribut yang digunakan dengan menggunakan data training:

a) Penyampaian Materi

$\Rightarrow \mathrm{P}(\mathrm{C})=\mathrm{P}($ Class $)$

$\mathrm{P}(\mathrm{Puas})=26 / 51=0,5098$

$\mathrm{P}($ Tidak Puas $)=25 / 51=0,4901$

b) Jenis Kelamin

Tabel 1 Perhitungan Atribut Jenis Kelamin

\begin{tabular}{|c|c|c|c|c|}
\hline & Puas & Tidak Puas & P(Puas) & $\begin{array}{c}\text { P(Tidak } \\
\text { Puas) }\end{array}$ \\
\hline $\mathrm{L}$ & 18 & 19 & $18 / 26$ & $19 / 25$ \\
\hline $\mathrm{P}$ & 8 & 6 & $6 / 26$ & $6 / 25$ \\
\hline & 20 & 25 & $100 \%$ & $100 \%$ \\
\hline
\end{tabular}


c) Penggunaan Media Daring

Tabel 2 Perhitungan Atribut Penggunaan Media Daring

\begin{tabular}{|c|c|c|c|c|}
\hline & Puas & Tidak Puas & P(Puas) & $\begin{array}{c}\text { P(Tidak } \\
\text { Puas) }\end{array}$ \\
\hline S & 22 & 20 & $22 / 5$ & $20 / 25$ \\
\hline KS & 3 & 4 & $3 / 26$ & $4 / 25$ \\
\hline TS & 1 & 1 & $1 / 26$ & $1 / 25$ \\
\hline & 26 & 25 & $100 \%$ & $100 \%$ \\
\hline
\end{tabular}

d) Mudah Berkonsentrasi

Tabel 3 Perhitungan Atribut Mudah Berkonsentrasi

\begin{tabular}{|c|c|c|c|c|}
\hline & Puas & $\begin{array}{c}\text { Tidak } \\
\text { Puas }\end{array}$ & $\begin{array}{c}\text { P } \\
\text { (Puas) }\end{array}$ & $\begin{array}{c}\text { P(Tidak } \\
\text { Puas) }\end{array}$ \\
\hline S & 5 & 3 & $5 / 26$ & $3 / 25$ \\
\hline KS & 16 & 12 & $16 / 26$ & $12 / 25$ \\
\hline TS & 5 & 10 & $5 / 26$ & $20 / 25$ \\
\hline & 26 & 25 & $100 \%$ & $100 \%$ \\
\hline
\end{tabular}

e) Kendala (Signal)

Tabel 4 Perhitungan Atribut Kendala(Signal)

\begin{tabular}{|c|c|c|c|c|}
\hline & Puas & $\begin{array}{c}\text { Tidak } \\
\text { Puas }\end{array}$ & $\begin{array}{c}\text { P } \\
\text { (Puas) }\end{array}$ & $\begin{array}{c}\text { P(Tidak } \\
\text { Puas) }\end{array}$ \\
\hline S & 25 & 25 & $25 / 26$ & $25 / 25$ \\
\hline KS & 1 & 0 & $1 / 26$ & $0 / 0$ \\
\hline TS & 0 & 0 & $0 / 26$ & $0 / 25$ \\
\hline & 26 & 25 & $100 \%$ & $100 \%$ \\
\hline
\end{tabular}

f) Suasana Pembelajaran

Tabel 5 Suasana Pembelajaran

\begin{tabular}{|c|c|c|c|c|}
\hline & Puas & $\begin{array}{c}\text { Tidak } \\
\text { Puas }\end{array}$ & $\begin{array}{c}\text { P } \\
\text { (Puas) }\end{array}$ & $\begin{array}{c}\text { P(Tidak } \\
\text { Puas) }\end{array}$ \\
\hline Membosankan & 13 & 13 & $13 / 26$ & $13 / 26$ \\
\hline Mendukung & 13 & 12 & $13 / 26$ & $12 / 26$ \\
\hline & 26 & 25 & $100 \%$ & $100 \%$ \\
\hline
\end{tabular}

g) Cara Mengajar

Tabel 6 Perhitungan Atribut Cara Mengajar

\begin{tabular}{|c|c|c|c|c|}
\hline & Puas & Tidak Puas & $\begin{array}{c}\text { P } \\
\text { (Puas) }\end{array}$ & P(Tidak Puas) \\
\hline Serius & 10 & 9 & $10 / 26$ & $9 / 25$ \\
\hline Menyenangkan & 3 & 6 & $3 / 26$ & $6 / 25$ \\
\hline $\begin{array}{c}\text { Menyenangkan } \\
\text { dan serius }\end{array}$ & 13 & 10 & $13 / 26$ & $10 / 25$ \\
\hline & 26 & 25 & $100 \%$ & $100 \%$ \\
\hline
\end{tabular}

h) Komunikasi

Tabel 7 Perhitungan Atribut Komunikasi

\begin{tabular}{|c|c|c|c|c|}
\hline & Puas & Tidak Puas & $\begin{array}{c}\text { P } \\
\text { (Puas) }\end{array}$ & $\begin{array}{c}\text { P(Tidak } \\
\text { Puas) }\end{array}$ \\
\hline $\mathrm{T}$ & 15 & 14 & $15 / 26$ & $14 / 25$ \\
\hline $\mathrm{KT}$ & 9 & 7 & $9 / 26$ & $7 / 25$ \\
\hline
\end{tabular}




\begin{tabular}{|c|c|c|c|c|}
\hline TT & 2 & 4 & $2 / 26$ & $4 / 25$ \\
\hline & 26 & 25 & $100 \%$ & $100 \%$ \\
\hline
\end{tabular}

Jadi, Hasil dari hitungan probabilitas posterior dari masing-masing tabel atau atribut yang digunakan yaitu

$\Rightarrow$ For Class Puas

$$
\begin{aligned}
& =18 / 26 \times 22 / 26 \times 5 / 26 \times 25 / 26 \times 13 / 26 \times 10 / 26 \times 15 / 26 \times(0,5098) \\
& =928125 / 77228944 \times(0,5098) \\
& =0,0120 \times 0,50980,0061
\end{aligned}
$$

$\Rightarrow \quad$ For Class Tidak Puas

$=19 / 25 \times 20 / 25 \times 3 / 25 \times 25 / 25 \times 13 / 26 \times 6 / 25 \times 14 / 25 \times(0,4901)$

$=9576 / 1953125 \times(0,4901)$

$=0,0049 \times 0,4901$

$=0,0024$

Jadi, dari hasil yang didaptkan probabilitas Puas > Tidak Puas

2. Pengujian Menggunakan RapidMiner Studio

Pengujian menggunakan rapidminer dengan menggunakan algoritma naïve bayes menggunakan data training dan data testing untuk dilakukan proses klasifikasi yaitu:
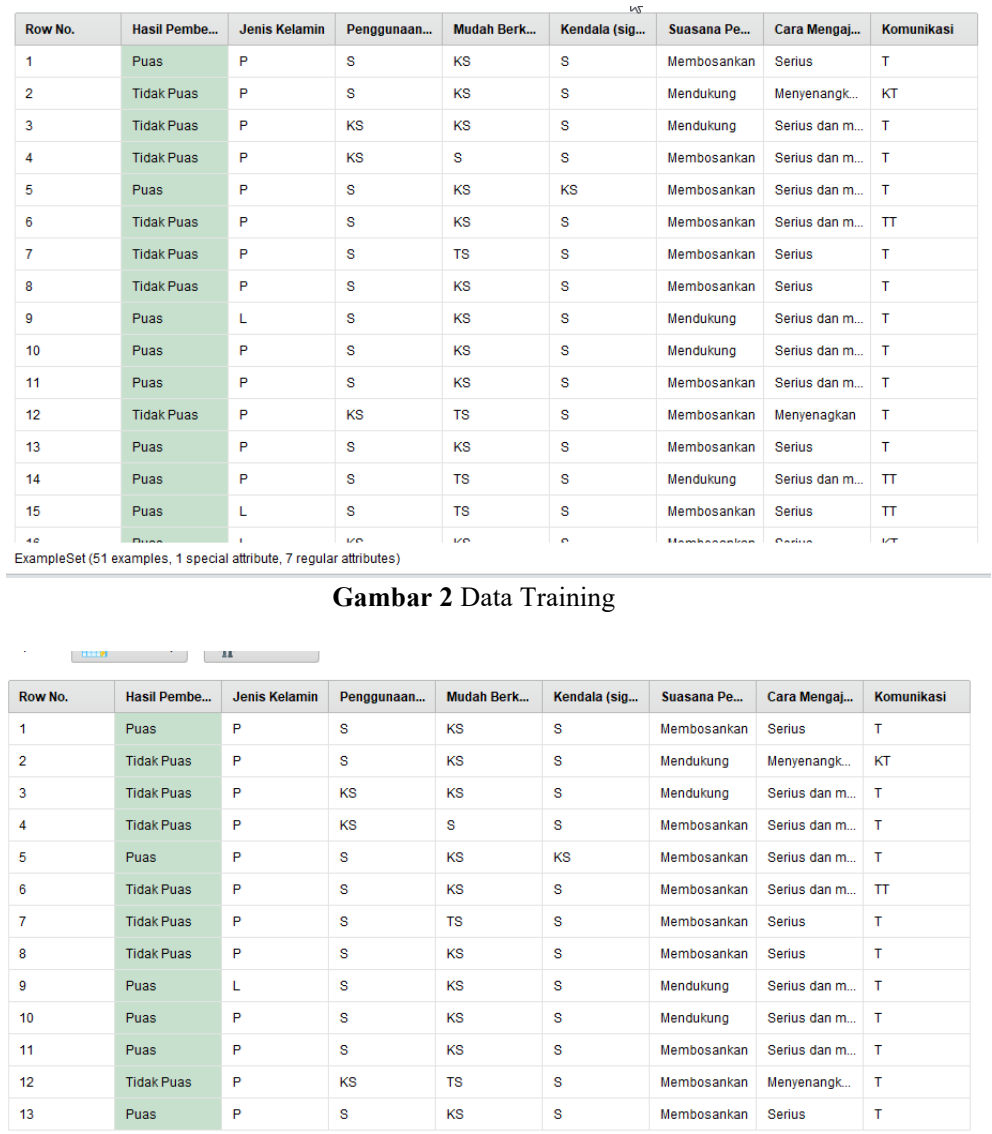

Gambar 3 Data Testing

Dari data training dan data testing yang sudah dilakukan, berikutnya yaitu dilakukan pemodelan dengan menggunakan algoritma naïve bayes. Maka hasil pengujian menggunakan rapidminer dengan mengklasifikasi 2 class yaitu puas dan tidak puas, selain accuracy ada dua hal yang dihasilkan dalam klasifikasi yaitu class precesion merupakan perbandingan dokomen dengan hasil yang relevan pda hasil query dan class recall perbandingan jumlah dokumen relevan terambil terhadap total dokumen relevan dengan akurasi yang didapatkan sebesar $76,92 \%$ dan class precission menghasilkan $100.00 \%$ dan class recall $57.14 \%$. Akan tetapi dari hasil yang telah didapatkan perlu ditinjau ulang Kembali dari jumlah dataset. 


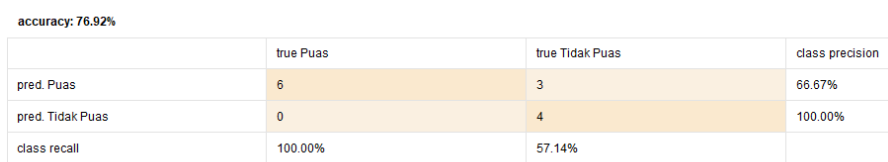

Gambar 4 Hasil Akurasi

Dengan hasil confidence puas dan tidak puas yang didapatkan yaitu sebagai berikut:

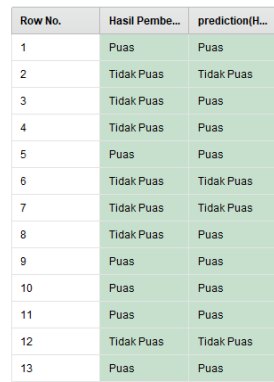

\begin{tabular}{|l|l|}
\hline confidencel.. & confidencel... \\
\hline 0.547 & 0.453 \\
0.026 & 0.974 \\
0.511 & 0.489 \\
0.661 & 0.339 \\
0.987 & 0.013 \\
0.398 & 0.602 \\
0.320 & 0.671 \\
0.547 & 0.453 \\
0.683 & 0.317 \\
0.605 & 0.395 \\
0.595 & 0.415 \\
\hline 0.185 & 0.815 \\
0.547 & 0.453 \\
\hline
\end{tabular}

\begin{tabular}{|l|l|}
\hline Jenis Kelamin & Penggunaan... \\
\hline P & S \\
\hline P & S \\
\hline P & KS \\
\hline P & KS \\
\hline P & S \\
\hline P & S \\
\hline P & S \\
\hline P & S \\
\hline L & S \\
\hline P & S \\
\hline P & S \\
\hline P & KS \\
\hline P & S \\
\hline
\end{tabular}

\begin{tabular}{|l|}
\hline Mudah Berk.. \\
\hline KS \\
\hline KS \\
\hline KS \\
\hline S \\
\hline KS \\
\hline KS \\
\hline TS \\
\hline KS \\
\hline KS \\
\hline KS \\
\hline KS \\
\hline TS \\
\hline KS \\
\hline
\end{tabular}

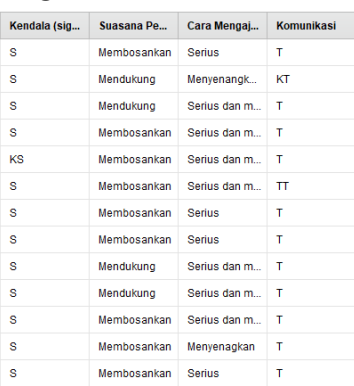

Gambar 5 Hasil Pemodelan Naive Bayes

Model distribusi dengan label penyampaain materi yaitu class puas : 7 distribusi dan class tidak puas : 7 distribusi atau hasil dari klasifikasi dengan 2 kelas yaitu puas dan tidak puas didapatkan untuk class puas $(0,510)$ dan class tidak puas $(0,490)$

\section{E. Evaluation Data}

Pada tahap evaluasi data dengan menggunakan nilai AUC dan Receiver Operating Characteristic (ROC) Curve untuk evaluasi dari metode klasifikasi yaitu algoritma naïve bayes

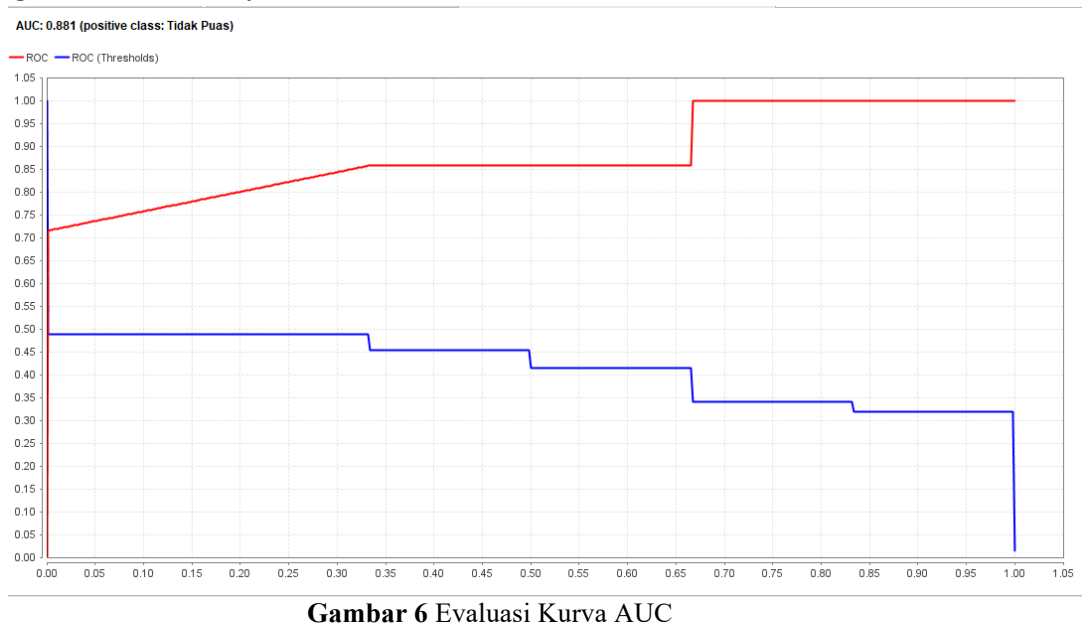

Jadi, dari 2 kurva dengan warna biru dan merah didapatkan kinerja dari warna biru lebih bagus atau dari gambar dapat dapat disimpulkan luas area kurva berwarna biru lebih besar dibanding luas area kurva berwar merah dengan nilai AUC 0.881mendekati angka 1 maka model yang dihasilkan baik.

\section{KeSIMPULAN}

Berdasarkan perhitungan data mining dengan metode klasifikasi menggunakan algoritma naïve bayes kesimpulan yang didapatkan dari data set yang diperoleh dengan 2 class puas dan tidak puas bahwa hasil pengujian algoritma naïve bayes ini diperoleh tingkat akurasi sebesar $76,92 \%$ dan class precission menghasilkan $100.00 \%$, class recall $57.14 \%$ dan nilai AUC 0.881 mendekati angka 1 jadi model yang dihasilkan baik. Jadi, dari hasil yang dapatkan tersebut teknik klasifikasi yang diuji coba dapat digunakan sebagai bahan untuk pengambilan keputusan tingkat kepuasan pembelajaran secara daring. 


\section{PENGAKUAN}

Tulisan in merupakan bagian dari penelitian yang dilakukan pada mahasiswa Pendidikan Bahasa Sastra Indonesia (PBSI) untuk klasifikasi tingkat kepuasan pada pembelajaran daring dilakukan secara mandiri

\section{DAFTAR PUSTAKA}

[1] R. H. S. Aji, "Dampak Covid-19 pada Pendidikan di Indonesia: Sekolah, Keterampilan, dan Proses Pembelajaran," Jurnal Sosial \& Budaya Syar-i, vol. Vol. 7 No. 5, pp. 395-402, 2020.

[2] M. Siddik, Hendri, . N. . R. Putri, . Y. Desnelita and Gustientiedina, "Klasifikasi Kepuasan Mahasiswa Terhadap Pelayanan Perguruan Tinggi Menggunakan Algoritma Naive Bayes," Journal of Information Technology and Computer Science (INTECOMS), vol. Volume 3 Nomor 2, pp. 162-166, 2020.

[3] Ibrahim, "PERPADUAN MODEL PEMBELAJARAN AKTIF KONVENSIONAL (CERAMAH) DENGAN COOPERATIF (MAKE - A MATCH) UNTUK MENINGKATKAN HASIL BELAJAR PENDIDIKAN KEWARGANEGARAAN," Jurnal Ilmu Pendidikan Sosial, sains, dan Humaniora, vol. Vol. 3 No. 2, pp. 199-211, 2017.

[4] E. S. Rosali, "Aktifitas Pembelajaran Daring Pada Masa Pandemi Covid19 di Jurusan Pendidikan Geografi Universitas Siliwangi Tasikmalaya," Geography Science Education Journal (GEOSEE), vol. eography Science Education Journal (GEOSEE), pp. 21-30, 2020.

[5] A. . P. Fadillah, "Penerapan Metode CRISP-DM untuj Prediksi Kelulusan Studi Mahasiswa Menempuh Mata Kuliah (Studi Kasus Universitas XYZ)," Jurnal Teknik Informatika dan Sistem Informasi, vol. Volume 1 Nomor 3, pp. $260-270,2015$.

[6] H. . K. Siradjuddin, "Penerapan Algoritma Naive Bayes Untuk Memprediksi Tingkat Kualitas Kesuburan (Fertility)," researchgate.net, pp. 1-14, 2015.

[7] M. W. Amelia, A. S. M. Lumenta and A. Jacobus, "Prediksi Masa Studi Mahasiswa dengan Menggunakan Algoritma Naïve Bayes," E-Journal Teknik Informatika, vol. Algoritma Naïve Bayes, pp. 1-7, 2017. 